3. Dreyfus H., Dreyfus S. From Socrates to Expert Systems: The Limits and Dangers of Calculative Rationality [Електроннийресурс] / Dreyfus Hubert L., Dreyfus Stuart Е. Режимдоступу: http://socrates.berkeley.edu/ hdreyfus/html/paper_socrates.html

4. Зимняя И.А. Общая культура и социально-профессиональная компетентность человека: [електронний ресурс] / Ирина Алексеевна Зимняя. - Режим доступу: // http://www.eidos.ru/journal/2006/0504.htm

5. Хуторской А.В. Ключевые компетенции и образовательные стандарты. [Електронний ресурс] / Хуторской Андрей Викторович. - Режим доступу: http://www.eidos.ru/journal/2002/0423.htm

6. Онаць О. М. Управління розвитком професійної компетентності молодого вчителя загальноосвітнього навчального закладу: автореф. дис. на здобуття наук. ступ. канд. пед. наук: 13.00.01 / Онаць Олена Миколаївна; Інститут педагогіки АПН України. К., 2006. - 21с.

7. Полубоярина I. I. Формування професійної компетентності майбутніх учителів музики в педагогічному коледжі : автореф. дис. на здобуття наук. ступ. канд. пед. наук: 13.00 .04 / Полубоярина Ірина Іванівна; Житомирський держ. ун-т ім. Івана Франка. Житомир, 2008. - 20 с.

8. Чемерис I. М. Формування професійної компетентності майбутніх журналістів засобами іншомовних періодичних видань: автореф. дис. на здобуття наук. ступен. канд. пед. наук: 13.00.04 / Чемерис Інна Михайлівна ; Інститут вищої освіти АПН України. - К., 2008. - 20c.

9. Лалак Н.В. Формування професійної компетентності майбутнього вчителя в процесі навчання історії: автореф. дис. на здобуття наук. ступ. канд. пед. наук: 13.00.02 / Лалак Наталія Володимирівна; Ін-т педагогіки АПН України. - К., 2009. - 20 с.

10. СікораЯ.Б Формування професійної компетентності майбутнього вчителя інформатики засобами моделювання : автореф. дис. на здобуття наук. ступ. канд. пед. наук: 13.00.04 / Ярослава Богданівна Сікора; Житомир. держ. ун-т ім. І.Франка. Житомир, 2010. - 20 с.

Стаття надійшла до редакції 24.05.2012 р.

УДК 371.15

О. Л. Титунь, викладач, Прикарпатський національний університет ім. В. Стефаника

\title{
НАУКОВО-ДОСЛІДНА РОБОТА ЯК ЗАСІБ ПІДВИЩЕННЯ ГОТОВНОСТІ МАЙБУТНІХ УЧИТЕЛІВ ДО ОРГАНІЗАЦЇ̈ ПОЗАКЛАСНОЇ ВИХОВНОЇ РОБОТИ 3 МОЛОДШИМИ ШКОЛЯРАМИ
}

Титунь О.Л. Науково-дослідна робота як засіб підвищення готовності майбутніх учителів до організаиії позакласної виховної роботи з молодшими школярами.

У статті розглянуто особливості науково-дослідної роботи з майбутніми вчителями. Така робота визначається як один з основних засобів підвищення готовності студентів до подальшої організачії позакласної виховної роботи з молодшими школярами.

Ключові слова: науково-дослідна робота, позакласна виховна робота, молодші школярі.

Титунь О.Л. Научно-исследовательская работа как способ повышения готовности будущих учителей к организации внеклассной воспитательной работы с младщими школьниками.

В статье рассматриваются особенности научно-исследовательской работы с будущими учителями. Научно-исследовательскую работу определяют как основной способ улучшения готовности к организачии внеклассной воспитательной работы со школьниками младших классов. 
Ключевые слова: научно-исследовательская работа, внеклассная воспитательная работа, школьники младших классов.

Titun $O$. The research work as a way to improve the readiness of prospective teachers to organize extra-curricular educational activities for younger students.

The article deals with the problem of peculiarities of research work of would-be teachers of primary school. The research work is considered to be one of the main factors of improvement of readiness to do extraclass activities with primary school pupils.

Key words: research work, would-be teachers of primary school, extraclass activities, primary school pupils.

Постановка проблеми. У контексті сучасних змін значної ваги у процесі оновлення суспільства набуває вища освіта, покликана формувати нову людину, здатну до самостійного розв'язання сукупності завдань, що ставлять суспільні та ринкові вимоги. Одним із показників успішності освіти $\epsilon$ самостійність студентів, яка виявляється у незалежності їхніх суджень і дій у процесі подолання навчальних труднощів.

Науково-дослідна робота $\epsilon$ не тільки одним із важливих засобів підвищення якості підготовки фахівців з вищою освітою, а також покликана формувати самостійність студентів у виборі організаційних форм виховної роботи у школі.

Аналіз досліджень. Проблема організації НДРС не $є$ новою, деякі аспекти проблеми організації самостійної роботи студентів можна простежити у фундаментальних працях 3 теорії та історії університетської освіти (К. Авраменко, А. Булда, І. Важинський, О. Глузман, Н. Демяненко, М. Свтух, I. Зязюн, В. Козаков, І. Кравченко, О. Сухомлинська, К. Ушинський). Умови підвищення організаційних засад самостійної пізнавальної діяльності учнів i студентів досліджували В. Козаков, П. Підкасистий, О. Рогова, М. Солдатенко та інші. Розкриттю особливостей самостійної пізнавальної діяльності учнів і студентів присвячені роботи Г. Александрова, В. Вергасова, М. Скаткіна та інших.

Метою статті $є$ визначити роль НДРС у підготовці студентів до організації позакласної виховної роботи з молодшими школярами.

Виклад основного матеріалу. НДРС є важливим чинником підготовки до організації позакласної виховної роботи з молодшими школярами. Саме НДР допомагає сформувати вкрай необхідні якості, що є важливими у майбутній професійній діяльності педагога. Кінцевою метою НДРС є поперше - формування у студентів наукового та творчого підходу до вивчення матеріалу та самостійної розробки методики виховної роботи, по-друге, озброєння конкретними знаннями, необхідними для самостійної організації виховної роботи, по-третє, забезпечення подальшого формування педагогічної позиції вчителя-вихователя, класного керівника [3; 4].

Висхідним положенням НДРС уважаємо основні принципи, на яких має грунтуватися ДНРС. На думку І. Вікторенко, основними принципами організації НДРС є:

1. Принцип гуманізації, який є чинником гармонійного розвитку особистості як суб'єкта творчої діяльності. Цей принцип спрямований на самоствердження майбутнього вчителя як цілісної, освіченої, духовно 
багатої, ініціативної, відповідальної особистості, здатної до інноваційної діяльності та конструктивної праці в проблемних ситуаціях.

2. Принцип демократизму, який спрямований на створення атмосфери рівноправних відносин між суб'єктами педагогічного процесу. Реалізація цього принципу $\epsilon$ передумовою повноцінного розкриття та розвитку творчого потенціалу кожного студента як особистості, як майбутнього спеціаліста.

3. Принцип самореалізації людини, що спрямована на забезпечення оптимальних умов для розвитку творчого потенціалу суб'єкта навчання i виховання, задоволення його інтелектуальних, духовних потреб i можливостей. Запровадження цього принципу, на думку I. Вікторенко, вимагає перебудови навчального процесу на засадах індивідуалізації, тобто відмови від традиційного для педагогічної системи зумовленого сприйняття людини виключно за критеріями успішності у навчанні.

4. Принцип емоційності. Викладач має виховувати у студентів уміння володіти своїм настроєм, емоціями, переживаннями, що забезпечить психічне благополуччя та психологічний комфорт.

5. Принцип активності, самодіяльності та творчої ініціативи. Цей принцип забезпечує навчальний діалог студента та викладача, що спрямований на спільну побудову програмної діяльності [2].

У межах дисертаційного дослідження було апробовано спеціальний курс «Методика організації позакласної виховної роботи в початковій школі». У зміст курсу покладено наступні ідеї:

- спецкурс «Методики організації позакласної виховної роботи в початковій школі» є логічним продовженням курсу «Методика виховної роботи»;

- розкриття кожної теми побудовано на трьох рівнях: теоретичному, методичному, технологічному, що сприяє розвитку педагогічного мислення;

- особливістю продуктивного вивчення курсу є тісний взаємозв'язок 3 практикою сучасної школи;

- залучення студентів до виконання науково-дослідних робіт. Зміст спецкурсу містить такі теми:

1. Роль та значення виховання в інформаційну добу людства.

2. Вплив глобалізаційних процесів на українську національна систему виховання.

3. Особистість педагога - вихователя в інформаційну добу людства.

4. Особливості організація позакласної виховної роботи з молодшими школярами.

5. Планування та методичний супровід позакласної виховної роботи у початкових класах.

6. Інноваційні технології організації виховної роботи в початкових класах. 
Оскільки спецкурс $є$ продовженням і поглибленням навчальнодослідної роботи, вчить збирати, систематизувати, аналізувати й узагальнювати матеріал, було запропоновано такі види роботи:

- аналіз наукової літератури з організації позакласної виховної роботи з молодшими школярами;

- систематизація матеріалів опрацювання літературних джерел;

- добір наукової літератури, складання бібліографій $з$ визначених тем;

- складання анотацій на вітчизняну та зарубіжну наукову літературу; написання рецензій на статті та книги;

- підготовка наукових повідомлень і рефератів.

Було запропоновано наступні теми рефератів:

1. Позакласні форми виховання у працях визначних вітчизняних педагогів.

2. Позакласна виховна діяльність у працях В. Сухомлинського.

3. Особливості організації позакласної виховної роботи в початковій школі.

4. Планування як результат конструктивної діяльності педагога.

5. Вплив ЗМІ на зміст позакласної виховної роботи початкової ланки освіти.

6. Виховний вплив Інтернету на дітей молодшого шкільного віку.

7. Формування морального імунітету проти негативного виховного впливу ЗМІ під час позакласної виховної роботи.

8. Виховний вплив дитячих сайтів на дітей молодшого шкільного віку.

9. Раціональне використання нових інформаційних технологій у виховному процесі.

10. Технології виховання як перспектива наукової організації позакласної виховної роботи в школі.

11. Соціально-моральний статус вчителя XXI століття.

Завдання з НДРС спрямовані на вивчення конкретної діяльності, а саме позакласної виховної роботи. Запропоновані завдання спецкурсу націлюють студента на проникнення у внутрішні процеси та явища організації позакласної виховної роботи, спонукають розкривати їх сутність та закономірності. Серед завдань, запропонованих у спецкурсі можна виокремити такі:

- Змоделюйте професійно важливі якості вчителя-вихователя сучасної школи (робота творчих груп студентів).

- Складіть картотеку публікацій про роль позакласної виховної роботи у формуванні особистості школяра молодшого шкільного віку за результатами сучасних досліджень.

- Законспектуйте основні положення М. Корфа, В. Вахтерова, П. Блонського, В. Дурдуківського, С. Шацького, Н. Болдирева, В. Сухомлинського про позакласну виховну роботу.

- Законспектуйте сучасні точки зору на позакласну виховну роботу у сучасній школі. 
- Підготуйте огляд статей із журналів та Інтернет ресурсів за останні 2 роки 3 питань впливу глобалізаційних процесів на виховання дітей молодшого шкільного віку.

- Дослідіть кілька перспективних планів-конспектів з виховної роботи в початковій школі. Зробіть загальні висновки щодо основної мети і завдань. Складіть план-конспект виховного заходу у початковій школі на тему: «Національне виховання в контексті глобалізаційних процесів».

- Проаналізуйте телевізійні програми задля визначення їх впливу на виховання особистості молодшого школяра.

- Відвідайте сайти загальноосвітніх шкіл (на вибір 4 школи в межах України). Порівняйте виховну роботу шкіл.

- Проаналізуйте та доведіть педагогічну цінність дитячих сайтів (http://levko.info, http://gnomik-nn.narod.ru, http://family.booknik.ru, http://www.sonyashnik.com).

- Підготуйте огляд статей із журналів та інтернет-ресурсів за останні 2 роки з питань безпеки дітей в Інтернеті.

- Відвідайте сайт www.microsoft.com Партнерство в навчанні. Завантажте навчально-методичний посібник «Виховання культури користувача Інтернету. Безпека у всесвітній мережі». Зробіть анотацію.

- Підготувати та провести соціальне опитування на тему: Вплив соціальних змін у суспільстві та інформаційної революції на статус вчителя. Підготувати доповідь.

- Вивчить періодичні видання за останні 3-5 років, доберіть матеріали щодо організації позакласної виховної роботи в початкових класах, проаналізуйте різні підходи до планування та здійснення позаурочної діяльності $з$ молодшими школярами, запропонуйте свої думки відносно означеної проблеми.

- Проаналізувати офіційні сайти шкіл України, підготуйте доповідь щодо загальної тенденції організації позакласної виховної роботи у сучасних умовах.

- Спроектуйте та підготуйте вікторину для дітей молодшого шкільного віку на тему «Безпека в Інтернеті».

- Використовуючи інтерактивні технології, підготуйте виховний захід на тему: «Безпека дітей в Інтернеті».

Під час проведення спецкурсу широко використовувались інноваційні методи: дискусії, ділові ігри. Звіти та доповіді дали змогу розвивати здібності щодо роботи з аудиторією, навички публічних виступів.

Отже, розроблення пропонованого спецкурсу, збільшення числа самостійних робіт, створення проблемних ситуацій на заняттях, застосування нетрадиційних методів навчання створили умови для розвитку творчих сил студента, необхідних для професійної організації позакласної виховної роботи у школі.

Ми переконані, що НДРС має бути скерованою не тільки на формування навичок виконання наукових робіт, а ще й на формування 
інформаційної компетентності, бо це надійніший і триваліший чинник, ніж знання зі спеціальності, які з часом втрачають актуальність. На нашу думку, запропоновані завдання уможливлюють формування означеного компонента професійної підготовки особистості, а також забезпечують багатовимірність iii руху в освітньому просторі.

\title{
Література
}

1. Буряк В. Умови та засоби самоосвіти студентів / В. Буряк // Вища школа. 2002. -№ 6. - C. 18-29.

2. Вікторенко І.Л. До питання про принципи організації самостійної роботи студентів / І.Л. Вікторенко // Вісник Черкаського університету. Серія педагогічні науки. Випуск 88. - Черкаси, 2006. - С. 9-13.

3. Рогова О.В. Формування пізнавальної активності студентів у процесі самостійної роботи / О.В. Рогова // Напрями наукових досліджень кафедри педагогіки. Педагогіка та психологія: [зб. наук. праць] ; за ред. В.І.Лозової. - Харків, 1997. - С. 39-41.

4. Ткаченко М.В. Самостійна робота студентів як чинник професійного становлення майбутнього фахівця / М.В. Ткаченко // Наука і освіта. - 2008. - №1-2. C. $107-110$.

Стаття надійшла до редакції 15.04.2012 р.

УДК 371.15

В. В. Шинкаренко,

acnipaнm,

Криворізький педагогічний інститут

ДВНЗ «Криворізький наиіональний університет»

\section{ЕТНО-ХУДОЖНЯ КУЛЬТУРА ЯК СКЛАДНИК ПРОФЕСІЙНОЇ КОМПЕТЕНТНОСТІ МАЙБУТНЬОГО ВЧИТЕЛЯ}

\begin{abstract}
Шинкаренко В.В. Етно-художня культура як складова професійної компетентності майбутнього вчителя.

У статті шилхом зіставлення, порівняння, узагальнення наукової інформації обтрунтовано слушність організачії навчального прочесу на основі народних традицій. Розкрито засоби й методи народного виховання, запропоновано рекомендаџї̈ з практичного використання отриманих результатів задля ефективного формування компетентності майбутнього вчителя.

Ключові слова: етно-художня культура, народне виховання, народні традииіі.

Шинкаренко В.В. Этно-художественная культура как составляющая профессиональной компетентности будущего учителя.

В статье на основе сопоставления, сравнение, обобщение научной информации обосновывается иелесообразность организации учебного прочесса на основе народных традиций. Раскрыты средства и методы народного воспитания, предлагаются рекомендачии с практического использования полученных результатов, с иелью компетентности будущего учителя.

Ключевые слова: этно-художественная культура, народное воспитание, народные традиции.

Shinkarenko V. Ethno-art culture as a component of professional competence of future teachers.

In the article on the basis of comparison, comparison, synthesis of scientific information, it is proposed teaching learning process, based on folk traditions. Means and methods are disclosed of public education, with recommendations to the practical use of the results, to the competence of future teachers.

Key words: ethnic and artistic culture, popular education, folk traditions.
\end{abstract}

Постановка проблеми. Перехід українського суспільства на новий етап - етап побудови незалежності держави - зумовив необхідність 